\section{American Screech Owls}

\section{By Cliff Shaw}

D URING FEBRUARY two American Screech owls were added to the records for the Yorkton district. According to Stuart Houston's list of "The Birds of the Yorkton District," there are four previous sight records, and Stuart lists the owl as rare, although thought to be a year-round resident.

The first owl was seen February 1 in the downtown area opposite the city hall, on third avenue, where it remained for most of the afternoon watching traffic from a maple tree. Shortly after dusk, Daryl Darling found the owl dead in Dr. Yaholnitsky's yard, where it had been crushed between a gate and fence.

The melting snow on February 19 uncovered a second specimen on Fifth Avenue. Both birds were of the grey phase.

\section{INGRATITUDE}

By E. Symons, Rocanville

GOR SEVERAL YEARS I have F wanted to obtain a couple of skunks, having heard from several observers that they make delightful pets. Finally I got two about the size of half-grown kittens-cost me $\$ 2.50$. They acted in a hostile manner but I thought they would soon tame down. They didn't-just got more hostile even though I tried to make friends with them. Finally I gave up in disgust and decided to give them a dose of cyanide. On my return I found that one had climbed out of the box and escaped. Just headed for the bush I thought O.K. then, I will give the other a dose.

About 11:45 that night the neighbor came in-almost in a cat-fit. There had been a skunk in her chicken house and lying there now were sixty dead and damaged chicks. I knew then. I little realized that a little fellow like that could do such a job. It was dead now; the boy had shot it. I went across at once and verified my fears. There were dead and wounded chickens all over the place. I guess her count was not far olit.
It cost me ten dollars to square myself with the lady. I believe she was generous at that. Now I don't trust skunks "no more!" They might be alright, though, if caught when tiny. These were obviously too old.

\section{Timber Wolves}

CLIFF SHAW reports that a 90 4 pound Timber Wolf was shot Feb. 22, 19 miles southeast of Yorkton by George Harvey, a farmer of the Wroxton district. The overall length of the animal was five feet, three inches plus tail of 18 inches. The girth back of the legs was 33 inches, ear six inches, height of shoulder 32 inches, length of head as over the forehead $12 \frac{1}{2}$ inches. It is not known whether the animal was fully matured. It was a male and was a very dark iron grey, as one.would refer to the coloring of a horse. It had a sprinkling of white guard hairs and a star on the chest 3 inches by one inch. The animal was first seen in the Storonway district 20 miles northeast of Yorkton.

\section{It Didn't Come Back for More}

By M. A. Kittle, Keewatin

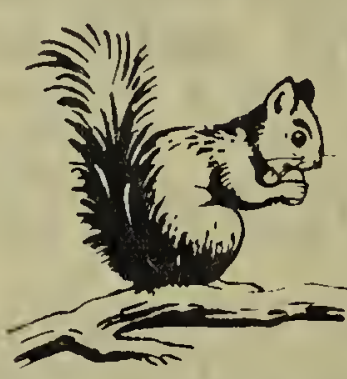

I WAS OUT at Spruce Lake one day early in March. Spring was in the air and so I sat down near the mouth of the Creek to have a smoke and look around. Soon I heard a squirrel chattering as he came closer and closer. $\mathrm{He}$ was a brave little fellow. First thing I knew he was on my feet, then my knee. He jumped to my shoulders and eventually landed on top of my head. As quick as a flash he darted down into my coat pocket, grabbed my chewing tobacco and started off for the tall timbers. I had been robbed. In spite of my age it did not take me long to catch him. I was determined he was not going to put anything over me, so I took out my knife, cut off a nice chunk and gave it to him with my compliments. I have not seen him since. 